\title{
SERVICE-LEARNING IN HIGHER EDUCATION: EXPERIENCES OF IMPLEMENTATION IN LITHUANIA
}

\author{
Monika Gruslytė \\ Klaipeda University, Lithuania
}

\begin{abstract}
The paper presents a review of the experiences in introducing service-learning as philosophy of, approach to and method of higher education in a number of universities in Lithuania over the latter years. The socio-cultural and educational adaptation of the concept that mainly originated in the USA primarily found the soil for being embedded in Siauliai University and the cases of continuing to present-day application of service-learning in Lithuanian environment of higher education as well as major approaches and principles that lead to and create unique experiences of Lithuanian higher education institutions contribute to enriching and enhancing higher education practices with students' competences and skills in bridging theory and practice, acquiring agency that potentially leads to a positive social change.

The aim of the investigation is to display the overviewed experiences of Lithuanian universities in embedding service-learning reaching for improved students' competences and skills as well as increased social awareness and agency.

The review demonstrates the experiences in adapting the concept of service-learning to European and Lithuanian socio-educational situation as well as the living need in updating, adjusting and revitalising service-learning as an educational innovation to meet the expectations set for higher education and challenges faced in real-world practice.
\end{abstract}

Keywords: civic engagement, critical service-learning, educational innovation, higher education, Lithuania, method of learning, service-learning.

\section{Introduction}

Raising relevant questions and discussing issues of contemporary higher education and innovative teaching, John Cowan provokingly describes teaching as "the purposeful creation of situations from which motivated learners should not be able to escape without learning and developing” (Cowan, 2002, p. 47). The need to bridge the gap between theory being taught at universities and practice tobe-acquired by prospective professionals continuously stimulates scholars and university teachers search for the ways allowing and enabling participants of the higher education process (students, teaching and administrative staff) acquire the skills and competences required for their professional performance seeking a positive change within society. Seeking and expecting that during their study 
period students would get acquainted not only with the content of the curriculum, gain specific abilities and skills, but also find the educational and social use and benefit of the taught course, develop their empathy, moral attitudes, form their inner need to help communities, advanced scholars and practitioners explore educational innovations and promote the opportunities to embed them in local socio-educational contexts. Seeking to more comprehensively relate academic study programmes driven by set learning outcomes to actual practice in a given socio-cultural situation, to bridge "the gap between academic, social and business spheres and adjust to the changing conception of higher education, i.e. to substitute the knowledge-oriented content with development of competences" (Barzelis, Barcytè, \& Mažeikienè, 2008, p. 264), several Lithuanian universities have taken up the idea of service-learning as a prospective educational innovation to be embedded in academic curricula. These relevant aspects lead to the aim of the present investigation to display the overviewed experiences of Lithuanian universities in embedding service-learning reaching for improved students' competences and skills as well as increased social awareness and agency.

\section{Lithuanian Modification(s) of Service-Learning}

In his research studies, professor Gintautas Mažeikis (2004; 2007) introduced and discussed the concept and experiences of practical implementation of the educational concept 'service-learning' in Lithuanian universities, taking the term 'learning' as methodically grounded self-development, personal participation in the process of development of specific skills and abilities. Challenging the post-modern paradigm of education and the necessity of social participation, he focuses on the altered treatment of partnership, includes participatory observation, critical thinking in the scope of educational methods, refers to the principle of dialogism, emphasises students' ability to cooperate, change competences, adapt in heterogenic teams. In this context, the term 'cooperation' is used broader than 'collaboration'; to be specific, "cooperation encompasses certain investment of own resources, own risk in common activities" (Mažeikis, 2007, p. 38). Moreover, he highlights the stimulation of students' cognitive, academic, social, civic and career skills (ibid.). Bearing in mind that the idea and term originated in the United States (McIlrath, Aramburuzabala, \& Opazo, 2019) and primarily spread through the discourse in the English language, special features and trajectories related to citizenship, civil societies and civic participation must be identified and acknowledged. To reason the transfer of the American historical and cultural tradition of service learning to Lithuanian socioeducational environment, scholar Natalija Mažeikienè explains the translation of 'service-learning' into Lithuanian as 'learning while serving the community', since it demonstrates the direct characteristics of the method 
(Mažeikienè, 2008, p. 6). Primarily, the term 'cooperative studies' has been introduced to adapt the service-learning method under the local conditions emphasising not the serving and provision of services but rather cooperation, collaboration, integration with other methods (ibid.). A combination of three elements: community service, purposeful academic learning, reflection, constitutes the essence of cooperative studies (ibid., 2008, p. 8). At the initial stage of implementation, the attempts were made to avoid a specific association of the term 'service learning', referring to other than higher education contexts where 'service' was regarded "either as a service in a Catholic and Christian sense, which doesn't always look relevant to this type of learning in Lithuania, or perceived in the light of Soviet ideology" (Aramburuzabala, Vargas-Moniz, Opazo, McIlrath, \& Stark, 2019, p. 232). Therefore, these negative associations reasoned the choice of 'cooperative studies' as an equivalent translation emphasising "reciprocal and mutual relations between local communities and universities” (ibid, p. 233). The English term 'service-learning' was used in brackets to supplement the adapted Lithuanian linguistic-sociocultural construct. Anyway, this breakthrough in the Lithuanian higher education theory and practice originated as an educational innovation ensuring creation of knowledge in a new, advanced way, providing favourable conditions for each student's selfdevelopment leading to becoming a socially active, creative, competent member of society, developing an in-depth understanding of the context and processes of learning (Valuckienè \& Tubutiene, 2008). It also allowed students perceive that reality is not static but dynamic and is constantly being re-arranged; moreover, the students found out that individuals and society are not static either; they had an opportunity to get acquainted with the labour market through practice, get a direct account of a future profession and test one's professional choices, build contacts with prospective employers (Vandzinskaite \& Ruškus, 2008). In general, service-learning appeared as the experience constructed by participants (Mažeikienè, Ruškus, \& Vandzinskaite, 2008).

Throughout several years of university practice, the conceptual modifications in higher education curriculum have been introduced, noting specific features of practical implementation of the service-learning method "depending on sociocultural factors of national and/ or regional contexts, historically and culturally formed institution of education as well as diverse characteristics of the pedagogical system" (Vandzinskaite, 2011, p. 153). In her doctoral research, Deivida Vandzinskaite emphasises that the Lithuanian case of service learning rather focuses on developing the civic mission of a university to enhance weak civic society (characteristic to post-communist countries) and promote societal, civic engagement and participation (Vandzinskaite, 2011). These preconditions determined the change in the content of the educational 
method turning it into "a creative construct of service learning and cooperative studies” (Vandzinskaite, 2011, p. 153).

Approaching service-learning (cooperative studies) from an administrative point of view, Laima Liukinevičienè argues that such studies seek "higher quality [...], more efficient interaction between higher education institution and region's environment, creation of high-quality human capital” (Liukinevičienè, 2008, p 10). She also emphasises that this study method allows university curricula actualise the current situation (ibid., p. 11). Service-learning, interpreted as 'cooperative studies', is related to social constructivism in the aspect of the ability to form people's competences, their communal participation, civic activeness and engagement (Mažeikis \& Lenkauskaite, 2008, p. 30). Moreover, a question is raised whether a student in organisation is a passive observer, investigator or an active contributor, catalyst of social processes (Vandzinskaite \& Mažeikienè, 2008, p. 109). Diverse approaches to the same modified concept demonstrate a multi-layer character of this method, though not pointing out the differences, but rather discussing its complexity and potential opportunities to be employed.

On the one hand, it should be noted that the survey of sociocultural adaptation of service-learning in higher education (Vandzinskaite, 2011) pointed out a number of challenges: diverse perception of the method, lack of students' abilities and motivation for independent learning, lack of teachers' didactic competences, to mention a few. Almost a decade ago these challenges were faced due to historically and socioculturally formed habits and behaviour, (mis-) perception of mutual learning in cooperation, diversity of participants who took part in the service-learning activities. On the other hand, dealing with the Lithuanian experience(s) in adapting and implementing service-learning, Mažeikienè points out the challenge of sustainability of service-learning in higher education: "[w]ithout local initiatives and essential efforts to promote civic engagement and citizenship education [...], service learning remains episodic and fragmentary practice with weak cultural and historical roots” (Preradović \& Mažeikienè, 2019, p. 191). All in all, the conceptualising and embedding of the education philosophy and method of service-learning in the post-Soviet country commenced, spread through several stages and continues developing regarding contemporary European trends and local insights.

\section{Service-Learning Revisited: Adding the Critical Dimension in Service-Learning}

The concept of service-learning has been revisited numerous times, and among the most recently published papers is a collective book encompassing case studies from twelve universities across Europe (Embedding Service-Learning in Higher Education. Developing a Culture of Civic Engagement in Europe, 2019). 
The collection of updated theoretical considerations and case studies puts emphases on experiences and issues faced while embedding service learning as a holistic pedagogical approach aiming to develop students' work-life skills, i.e. communication, team-working and social skills as well capacities in project-work, problem-solving, information literacy, communication, technological familiarity, time management, leadership, enhancing the integration of a pro-social disposition in young professionals-to-be, developing their civic-engagement competencies. Being aware that service learning is often confused with other experiential learning practices, such as internships, field studies and volunteer activities, scholars and practitioners implementing service-learning in universities focus on civic engagement, integration of community service and critical thinking with academic learning of students encouraging them consider the roles of protagonists assuming agency contributing to the positive social change as well as addressing global challenges.

To point out the difference among various approaches to gaining work-life skills while proceeding with educational activities, Andrew Furco draws 'the balance beam' which locates five "service-focused experiential learning practices": volunteering and internship activities at the bottom level, situated in a distance between each other (this way demonstrating that recipients of the service benefit more in the case of volunteering; whereas in the case of internship a student (as provider) focuses more on and benefits from learning); the middle level is taken by community service and field education which are situated next to each other, with field education giving more educational benefit to a student, rather than community service stronger favouring recipients; and we find service learning at the top, demonstrating that the latter embraces, grounds on the features, practices and experiences of the other ones drawn below (Furco \& Norvell, 2019, p. 21). To sum up, in the case of service learning, "the experience is intentionally built to focus on ensuring learning for the service provider (the student) and service for the recipient of that service (the community member or agency), [...] to intentionally benefit both" (ibid.).

Additionally, the insertion of the hyphen between 'service' and 'learning' (i.e. service-learning) is substantiated by the reciprocity and mutual benefit to both recipient and provider, service and learning, which are foundational to the concept encompassing the symbiotic relationship (ibid., p. 22). Both versions (hyphened and non-hyphened) appear in scholarly papers (author's note: intentionally choosing the hyphenation in the present paper to emphasise the reciprocity).

Educational innovations continue contributing to the development of students' competences; the aspect of their consciousness-raising is vital in and for civic society. Gradually, the curricula are being enhanced with critical approaches to the educational content and graduates' agency. Seeking to enhance the social impact of service learning as both method of teaching/ learning and philosophy, 
critical service-learning is being embedded in higher education theory and practice over the latter two decades. The purpose is to "encourage students to think critically about social issues and act creatively to produce change" (Mitchell, 2007, p. 101). In this aspect, research papers share experiences in designing and implementing study programmes seeking to "develop in students the skills, knowledge, experience, and commitment to work collaboratively with others for social change in their communities" (ibid., p. 103), embed it as "the act of service, of community involvement that changes the traditional learning experience" (ibid., p. 107). Moreover, critical service-learning experiences may give students "a different perspective of the agency and its contribution to community, as well as a deeper understanding of the community served" (ibid., p. 108). Further developing the advancement of service-learning embracing the critical dimension, Tania D. Mitchell differentiates the components of the socalled traditional service-learning and critical service-learning (Mitchell, 2008). In the first instance, she points out the components 'learning to serve' and 'serving to learn' taking place within community and classroom; whereas in the second case she highlights 'a social change orientation', 'working to redistribute power' and 'developing authentic relationships', designing them also happening in community and classroom environment. These two models of service-learning as pedagogy are powered with students' reflection, active engagement and agency. Moreover, critical service-learning may be employed seeking to address the ways in which civic engagement can become repositioned and revitalised (Preradović \& Mažeikienè, 2019). These competences are required in present-day university curricula to meet the occurring challenges in local (Lithuanian) communities and discussed globally.

After consideration of various contemporary educational and social issues viewed in connection, the team of researchers and education practitioners (who have been working on implementation of an international project "Europe Engage”), revealing an emerging "unique European version of service learning" (Furco \& Norvell, 2019, p. 32), have produced (in 2017) an updated quite extensive definition of service-learning:

Service-learning (sometimes referred to as community based or community engaged learning) is an innovative pedagogical approach that integrates meaningful community service or engagement into the curriculum and offers students academic credit for the learning that derives from active engagement within community and work on a real world problem. Reflection and experiential strategies underpin the learning process and the service is link to the academic discipline. Service learning brings together students, academics and the community whereby all become teaching resources, problem solvers and partners. In addition to enhancing academic and real world learning, the overall purpose of service learning is to instil in students a sense of civic engagement and responsibility and work towards positive social change within society. (Project "Europe Engage") 
The approaches and practices of implementation of service-learning as an educational innovation comprise a set of cultural and historical complexities (Mažeikiene, 2019), reflect the culture and priorities of each country and region where it has emerged (Furco \& Norvell, 2019). Thus, continuous revisiting of the theories and practices of implementation is required and the contextualisation of the very concept of service-learning needs to be discussed further.

\section{Service-Learning in University Education Projects}

Relevance of the service-learning has also been acknowledged and proven by international projects bringing academic communities of different countries together to discuss and solve the challenges of this educational method in the aspects of identification of its need, implementation of it, development of the culture of education and engagement of community members. Service-learning was first introduced in Šiauliai University (Lithuania) thanks to the projects led and funded by the US government and other institutions; this opened opportunities to get acquainted with and embed democratic changes and strengthen civic society in post-Soviet Lithuania (Preradović \& Mažeikienè, 2019). However, it "was perceived as a 'borrowing' of a culturally ‘alien' educational strategy that needed to be adapted and adjusted to the local context (ibid., 188). Another influence was related to "the fostering of citizenship education and service learning by the EUfunded projects" (ibid.). Among the first ones, the project "Kooperia" in the early 2000s, bringing together higher education institutions and communities, gave the floor for systemic and broad-scale implementation of service-learning.

A decade later, to name other significant examples, the project "Europe Engage - Developing a Culture of Civic Engagement through Service-Learning within Higher Education in Europe" in the framework of the Erasmus+ programme that lasted throughout 2014-2017 made a significant contribution to creating a culture for service-learning in higher education (Project "Europe Engage"). Another relevant international Erasmus+ Knowledge Alliances project, "Rural 3.0: Service Learning for the Rural Development", is being currently implemented and covers the period 2018-2021 (Project "Rural 3.0: Service Learning for the Rural Development"). Among more than a dozen of European universities taking part in these two latter projects, Lithuania is represented, too: researchers from Vytautas Magnus University contribute to development of this advanced method stimulating consciousness-raising of society members through embedding service-learning in university curricula. Kaunas University of Technology (Lithuania) is currently implementing (2018-2021) Erasmus+ project "Engage Students" which is dedicated to development of students' social responsibility by integrating the service-learning method in curricula of higher education institutions (Project "Itrauk studentus"). The overall goal of the project 
is "to enhance the social aspect in higher education, to increase importance of higher education in society by integrating service-learning into educational and research practice" (ibid.).

Even though the idea to introduce the concept of service-learning in Lithuanian higher education appeared as far back as in 2004 (Mažeikis, 2004) under the influence of the US sociocultural tradition, it has been creatively interpreted, initially implemented and scientifically investigated by 2011 (Barzelis, Barcytè, \& Mažeikienė, 2008; Liukinevičienè, 2008; Mažeikienè, 2008; Mažeikienè, Ruškus, \& Vandzinskaitė, 2008; Mažeikis, 2007; Mažeikis \& Lenkauskaitė, 2008; Valuckienė \& Tubutienè, 2008; Vandzinskaitė \& Mažeikienè, 2008; Vandzinskaitė \& Ruškus, 2008; Vandzinskaitè, 2011). Grounding on the lessons learnt, the changing societal mentality in relation to the service-learning as an educational philosophy and method, closely connected to experiential learning, civic engagement and cooperation, higher education continues revisiting and expanding the approaches and practices leading to positive social change and benefit to all parties involved. The continuous development of service-learning being embedded in Lithuanian higher education institutions needs not only impetus, but also requires sustainability and support; therefore, international projects greatly contribute to the spread and advancement of this educational approach.

\section{Conclusions}

Scientific papers and monographs dealing with implementation of servicelearning in universities display a variety of approaches, give evaluation of experiences, as seen from learners' teachers', administrative staff's perspectives. They all consider the challenges and opportunities taken by universities to enrich and enhance student education this way bridging theory and practice, endowing students, future professionals, with competences and skills as well as increased social awareness and agency required for their professional performance, especially in the social area.

The paradigm shift of service-learning and critical service-learning, the transition in the approach to higher education led by the goal to educate professionals who are socially-conscious, active citizens capable of demonstrating their agency, having work-life skills and having experience-based knowledge of culture they are about to immerse in as professionals likely leading to a positive social change in society drive the educational innovation further.

Grounding on the experiences in adapting the concept of service-learning as a culture of civic engagement to Lithuanian socio-educational situation as well as the living need in updating, adjusting and revitalising service-learning as an educational innovation to meet the expectations set for higher education and 
challenges faced in real-world practice prospective higher education institutions, prominent scholars and conscious communities continue exploring the opportunities and reaching for new goals.

\section{References}

Aramburuzabala, P., Vargas-Moniz, M.J., Opazo, H., McIlrath, L., \& Stark, W. (2019). Considerations for Service Learning in European Higher Education. In Aramburuzabala, P., Mcllrath, L. \& Opazo, H. (Eds.). Embedding Service-Learning in Higher Education. Developing a Culture of Civic Engagement in Europe. (pp. 230-242) Routledge: Taylor \& Francis. DOI: https://doi.org/10.4324/9781315109053

Barzelis, A., Barcytè, L., \& Mažeikienė, N. (2008). Tarpkultūrinès kompetencijos ugdymas ir raiška kooperuotose studijose (service-learning). Kooperuotu studiju sociokultūrine adaptacija Lietuvoje. Mokslo studija. N. Mažeikienè (Comp.). Šiauliai: Šiaulių universiteto leidykla, 262-327.

Cowan, J. (2002). On Becoming an Innovative University Teacher. Reflection in Action. Buckingham: The Society for Research into Higher Education \& Open University Press.

Embedding Service-Learning in Higher Education. Developing a Culture of Civic Engagement in Europe. (2019). Aramburuzabala, P., McIlrath, L. \& Opazo, H. (Eds.) Routledge: Taylor \& Francis. DOI: https://doi.org/10.4324/9781315109053

Furco, A., \& Norvell, K. (2019). What Is Service Learning? Making Sense of the Pedagogy and Practice. In Aramburuzabala, P., McIlrath, L. \& Opazo, H. (Eds.). Embedding ServiceLearning in Higher Education. Developing a Culture of Civic Engagement in Europe (pp. 13-35). Routledge: Taylor \& Francis. DOI: https://doi.org/10.4324/9781315109053

Liukinevičienè, L. (2008). Kooperuotos studijos: organizavimas ir administravimas aukštojoje mokykloje. Studiju pagal KS metoda organizavimo ir kokybès vertinimo metodika. Šiauliai: Šiaulių universiteto leidykla.

Mažeikienė, N. (2008). Projektas KOOPERIA: kooperuotų studijų (sevice-learning) adaptacija ir veiksmingumo tyrimas. Kooperuotu studiju sociokultūrine adaptacija Lietuvoje. Mokslo studija. N. Mažeikienè. (Comp.). Šiauliai: Šiaulių universiteto leidykla, 6-29.

Mažeikienè, N., Ruškus, J., \& Vandzinskaitè, D. (2008). Kooperuotų studijų (service-learning) edukacinis poveikis: projekto KOOPERIA dalyvių apklausos rezultatai. Kooperuotu studiju sociokultūrinè adaptacija Lietuvoje. Mokslo studija. N. Mažeikienè. (Comp.) Šiauliai: Šiaulių universiteto leidykla, 215-261.

Mažeikienė, N. (2019). Understanding the Evolution of Service Learning at European Universities: Insights from Actor-Network Theory. In: Aramburuzabala, P., Mcllrath, L \& Opazo, H. (Eds.). Embedding Service-Learning in Higher Education. Developing a Culture of Civic Engagement in Europe (pp. 93-108). Routledge: Taylor \& Francis. DOI: https://doi.org/10.4324/9781315109053

Mažeikis, G. (2004). Kooperuotu studiju vadovas. Šiauliai: Šiaulių universiteto leidykla.

Mažeikis, G. (2007). Kompetencijų ugdymo sistema taikant kooperuotų studijų metodą. Mokymosi tarnaujant bendruomenems (service learning) adaptacija Lietuvoje. Mokslo monografija. Šiauliai: Šiaulių universiteto leidykla.

Mažeikis, G., \& Lenkauskaité, J. (2008). Kooperuotų studijų (service-learning) adaptavimas Lietuvoje hermeneutinès pedagogikos požiūriu. Kooperuotu studiju sociokultūriné adaptacija Lietuvoje. Mokslo studija. N. Mažeikienè. (Comp.). Šiauliai: Šiauliu universiteto leidykla, 30-104. 
Gruslytè, 2020. Service-Learning in Higher Education: Experiences of

Implementation in Lithuania

McIlrath, L., Aramburuzabala, P., \& Opazo, H. (2019). Europe Engage: Developing a Culture of Civic Engagement through Service Learning within Higher Education in Europe. In Aramburuzabala, P., McIlrath, L. \& Opazo, H. (Eds.). Embedding Service-Learning in Higher Education. Developing a Culture of Civic Engagement in Europe (pp. 69-80). Routledge: Taylor \& Francis. DOI: https://doi.org/10.4324/9781315109053

Mitchell, D.T. (2007). Critical Service-Learning as Social Justice Education: A Case Study of the Citizen Scholars Program. Equity \& Excellence in Education, 40, 101-112, DOI:10.1080/10665680701228797

Mitchell, D.T. (2008). Traditional vs. Critical Service-Learning: Engaging the Literature to Differentiate Two Models. Michigan Journal of Community Service Learning, Spring 55-65.

Preradović, N.M., \& Mažeikienė, N. (2019). Service Leaning in Post-communist Countries: Lithuania and Croatia. In Aramburuzabala, P., McIlrath, L. \& Opazo, H. (Eds.). Embedding Service-Learning in Higher Education. Developing a Culture of Civic Engagement in Europe (pp. 180-195). Routledge: Taylor \& Francis. DOI: https://doi.org/10.4324/9781315109053

Project "İtrauk studentus" ["Engage Students"]. Internet access at https://ktu.edu/ projects/itrauk-studentus-studentu-socialines-atsakomybes-ugdymas-integruojantmokymosi-tarnaujant-bendruomenei-metoda-i-aukstojo-mokslo-instituciju-mokymoprograma

Project "Europe Engage - Developing a Culture of Civic Engagement through Service-Learning within Higher Education in Europe“. Internet access at https://europeengage.org

Project "Rural 3.0: Service Learning for the Rural Development". Internet access at http://theta.ffzg.hr/ruralhub/Survey/LAG

Valuckienè, J., \& Tubutienè, V. (2008). Edukacinès paradigmos virsmo galimybės ir problemos taikant kooperuotų studijų (service-learning) metodą. Kooperuotu studiju sociokultūrinė adaptacija Lietuvoje. Mokslo studija. N. Mažeikienè. (Comp.) Šiauliai: Šiauliu universiteto leidykla, 166-193.

Vandzinskaitè, D., \& Mažeikienè, N. (2008). Kooperuotų studijų (service-learning) atvejų analizè, arba projekto KOOPERIA išmoktos pamokos. Kooperuotu studiju sociokultūrinè adaptacija Lietuvoje. Mokslo studija. N. Mažeikienè. (Comp.) Šiauliai: Šiaulių universiteto leidykla, 105-165.

Vandzinskaitė, D., \& Ruškus, J. (2008). Žinojimo demokratizavimas tiriant kooperuotų studijų (service-learning) veiksmingumą: focus grupès dalyvių balsai. Kooperuotu studiju sociokultūrine adaptacija Lietuvoje. Mokslo studija. N. Mažeikienė. (Comp.) Šiauliai: Šiaulių universiteto leidykla, 194-214.

Vandzinskaité, D. (2011). Mokymosi tarnaujant bendruomenei sociokultūrinè adaptacija Lietuvos universitete. Daktaro disertacija. Šiauliai: Šiaulių universiteto leidykla. 